\title{
Evaluation of a Technetium-99 Detector Based on Laboratory Testing for Use in In-Situ Vadose Zone Applications
}

F.M. Mann and D.A. Myers

Washington River Protection Solutions

Richland, WA 99352

U.S. Department of Energy Contract DE-AC27-08RV14800

$\begin{array}{ll}\text { EOTIECN: } & \text { UC: } \\ \text { Cost Center: } & \text { Charge Code: } 200398 \\ \text { B\&R Code: } & \text { Total Pages: } 32\end{array}$

Key Words: technetium detector, vadose zone

Abstract: This document evaluates the feasibility of in-situ deteclion of technetium-99 in Hanford Site vadose zone soils (the soils between the surface and groundwater) using laboratory tests.

The detector system performs adequately for high technetium concentration, but more development and laboralory testing is needed before field demronstration is performed.

TRADEMARK OISCLAIMER. Reference harein to any spectific commercial product, procass, of service by trada neame, trademark, manufactumer, or otherwits, does not necessarity conslitule or imply lis endorsement, recommendetion, or fawaring by the United Slates Government or diny sancy thereof or its contractors or subcontractors.
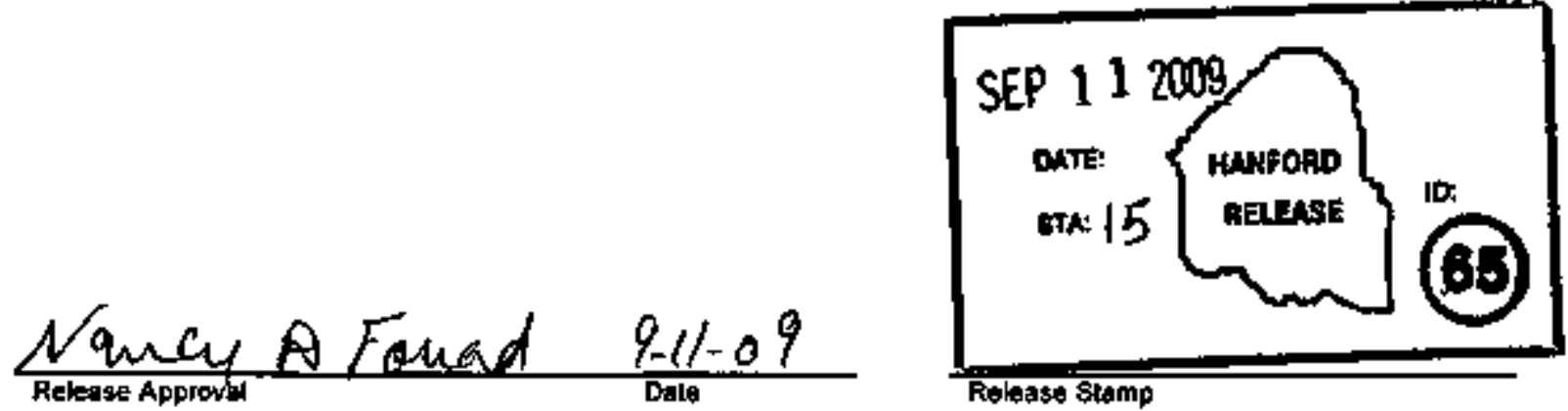

Approved For Public Release 


\section{RPP-ENV-42667. Rev, 0}

\section{Executive Summary}

This document evaluates the feasibility of in-situ detection of technetium-99 $\left({ }^{99} \mathrm{Tc}\right)$ in Hanford Site vadose zone soils (the soils between the surface and groundwater) using laboratory tests.

The detector sysiem performs adequately for high technetium concentration, but more development and laboratory testing is needed before field demonstration is performed.

The detector system clearly detects a 100.8 nanoCurie surtace-deposited source of ${ }^{90} \mathrm{Tc}$. The display system monitoring the tests shows that the detection system and the associated electronics can detect ${ }^{99} \mathrm{Tc}$ in the preseuce of potassium-40 $\left({ }^{40} \mathrm{~K}\right)$ when the ${ }^{99} \mathrm{Tc}$ amount is large.

This report recommends that future work consist of

- Further testing using the current proof-of-principle detector system

- Discussions with Hanford Site staff on needed requirements for field testing and deployment

- Development and testing of a second (and possibly third) prototype detector

- Development of a new ${ }^{99}$ Tc Detector System suitable for field testing

- Hauford Site laboratory and fjeld testing of an integrated. ruggedized. field-ready, downhole detector system ready for Hanford Site deployment 


\section{Table of Contents}

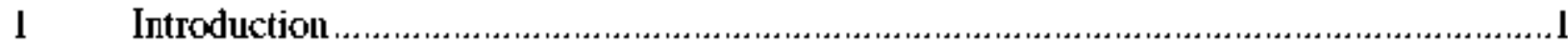

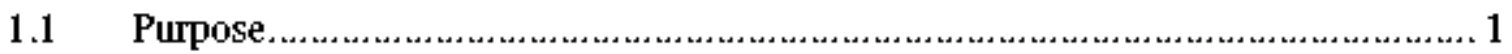

1.2 Stalement of Problem................................................................................ 1

1.3 Background …...........................................................................................

1.4 System Description ..........................................................................

1.5 Structure of the Document ...............................................................................2

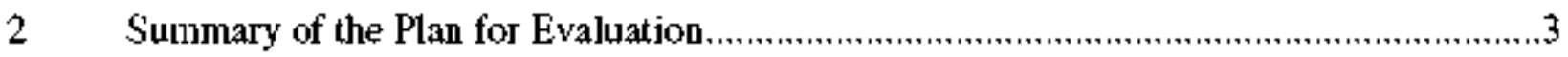

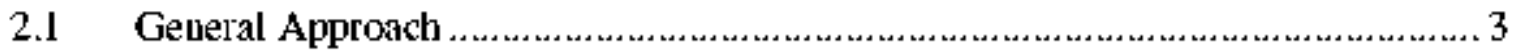

2.2 Sample Preparation ............................................................................................ 3

2.3 Hardware Description ........................................................................... 4

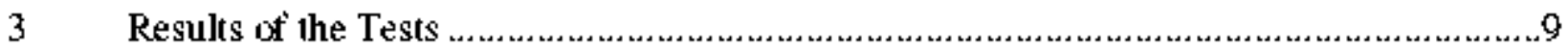

$3.1{ }^{99}$ Tc Point Source Testing ............................................................................ 9

$3.2{ }^{99} \mathrm{Tc}$ Point Source and $30 \mathrm{pC} / \mathrm{g}$ Soil Sample Testing ...................................... 10

3.3 Soil Sample Testing ....................................................................................... 10

4 Analysis of the Testing and Reconmendations on Future Work …...............................13

4.1 Analysis of the Testing .......................................................... 13

$4.1 .1{ }^{90} \mathrm{Tc}$ Point Source Testing............................................................ 13

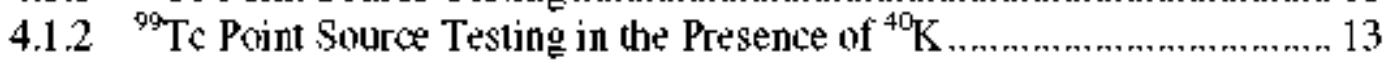

4.1.3 Soil Sample Testing..................................................................... 13

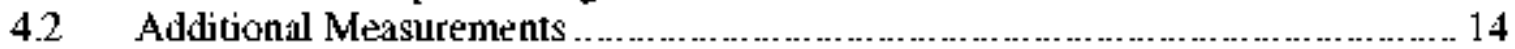

4.3 Observations of Additional Measurements ..................................................... 17

4.4 Recommendations for Future Work................................................. 19

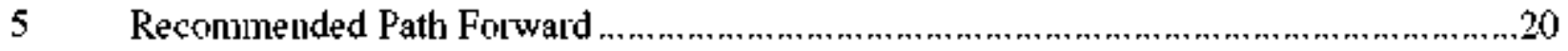

5.1 Further testing at INL usiug the current detector system................................. 20

5.2 Discussions with Hanford Site staff on needed requirements for field testing and deployment .......................................................................................... 20

5.3 Development and testing of a new ${ }^{99}$ Tc prototype detector system.................. 21

5.4 Development of a field deployable detector system...................................... 22

5.5 Laboratory and field testing of a field deployable detector system at the Hanford

Site ....................................................................................... 22

5.6 ROM Schedule and Cost for Recommended Path Forward .................................25

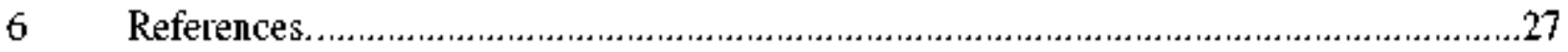




\section{Lis1 of Figures}

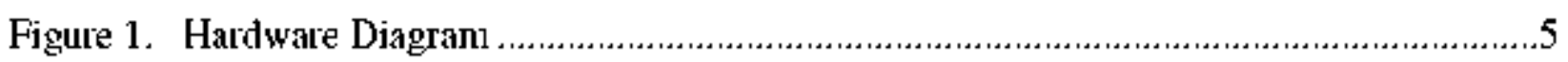

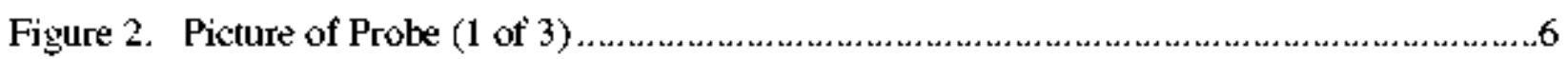

Figure 3. Picture of Probe (2 of 3) f...................................................................................

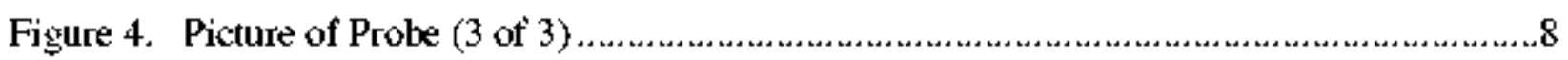

Figure 5. Relationship between ${ }^{99} \mathrm{Tc}$ Point Counts and Distance from the Detector .....................10

Figure 6. Photograph of Soil Sample Counting ..................................................................... 1

Figure 7a. Relationship betwees ${ }^{99} \mathrm{Tc}$ Counts from Soil Samples and Distance from the Detector 11

Figure $7 \mathrm{~b}$. Relationship between ${ }^{40} \mathrm{~K}$ Counts from Soil Samples and Distance fron the Detector 12

Figure 8. Photograph of Detector Face after Soil Testing. ..............................................14

Figure 9. Detector and Soil Samples Set-Up for September 1 measurements............................14

Figure 10. Time Responses for the 30pCi/g Soil Sample ...........................................................16

Figure 11. Time Responses for the 500pCi/g Soil Sample ...........................................................16

Figure 12. Time Responses for the 30pCi/g Soil Sample and Point ${ }^{99} \mathrm{Tc}$ Sample .........................17

\section{List of Tables}

Table 1. Vadose Zone Sediments to Be Used to Create Testing Samples ..................................4

Table 2. MFC. System Components ......................................................................4

Table 3. Results of ${ }^{99} \mathrm{Te}$ Point Source Measurements....................................................9

Table 4. Results of Soil Sample Measurements.......................................................................12

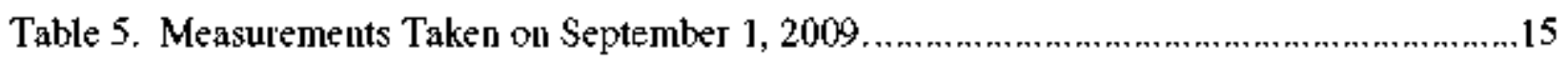

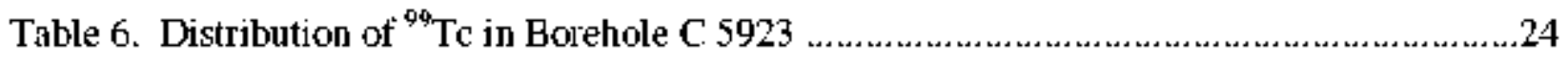

Table 7. ROM Schedule and Cost for Proposed Path Forward ..................................................25 


\section{RPP-ENV-42667. Rev, 0}

\subsection{Purpose}

\section{Introduction}

The purpose of this document is to present the results of laboratory conducted prof-of-concept tests and to evaluate the feasibility of iu-situ detection of technetium-99 ("\%) vadose zone soils (the soils between the surface and groundwater) using laboratory tests.

\subsection{Statement of Problem}

Large (capacity of $-1,000,000$ gallons) underground tanks at the Hanford Site have been used and are being used to store radioactive and chemically hazardous waste from the processing of irradiated nuclear fuel. Some of these tanks have released contamination into the soil. Washinglon River Protection Solutions, LLC (WRPS) is under contract to the U.S. Department of Energy (DOE) to manage these tanks.

Because of its abundance, half-life, mobility, and toricity, ${ }^{99} \mathrm{Tc}$ is considered a major contaminant of concern. However, ${ }^{99} \mathrm{Tc}$ is difficult to detect in-situ because of its low-energy radiation. Measurements of ${ }^{48} \mathrm{~T} \mathrm{c}$ soil concentrations are usually obtained by collecting soil samples and measuring their concentrations in a laboratory.

This effort evaluates whether an in-situ ${ }^{99} \mathrm{Tc}$ detector can be developed. The first step (covered in this plan) is to perform laboratory measurements to determine if the radiation from ${ }^{99} \mathrm{Tc}$ decay can be detected and discriminated from the orher radiation (mostly natural) contained in Hanford soils. If the first step is successful, an integrated ruggedized field-ready down-hole detector system will be demonstrated in the field as a direct push probe hole is decommissioned.

If the field demonstration is successful, the integrated ${ }^{99} \mathrm{Tc}$ detector system will join the set of tools used to characterize the vadose zone. After a direct push probe hole is pushed to the desired depth, gamma and neutron logging tools are used to determine the distribution of strongly gamma-emitting radionuclides and of moisture content, respectively. As the probe hole is decomnissioned. the ${ }^{99} \mathrm{Tc}$ detector would be used to determine the distribution of ${ }^{99} \mathrm{Tc}$ in the vadose zone. With this information. depths can be selected at which sanjples would be obtained for laboratory analysis using a second direct push probe hole.

\subsection{Background}

Background information on the Hanford Site, past vadose zone characterization effort and methods. vadose zone concentrations, and the nuclear physics associated with the detector are documented in Section 1.3 of the Evaluation Plan for an Itt-Situ Vadose Zone Technetium-99 Detector (RPP-ENV-42008).

\subsection{System Description}

The systen tested consists of a multi-element detector specific for ${ }^{99} \mathrm{Tc}$, which is optimized to reduce background effects in the outer ${ }^{99} \mathrm{Tc}$ detector element, associated electronics (including a pulse shape discrimination system), and a power supply. The ${ }^{99} \mathrm{Tc}$ detector is composed of two 
cylindrically coupled scintillators with different decay time constants. By discriminating on the pulse shape, one can distinguish interactions in either scintillator with a common photomultiplier tube. The system lested was not ruggedized nor configured for down-hole deployment.

However. the detector was sized to accommodate a 1.25-inch inside diameter push tube to ensure that detector efficiency and laboratory test results are consistent with requirements anticipated for field deployment.

\section{Structure of the Document}

This section provides background material for the evaluation of the ${ }^{\text {wy }} \mathrm{Tc}$ detector. Section 2 presents the sumnaty of the Evaluation Plan for an In-Situ Vadose Zonte Technetiun-99 Detector (RPP-ENV-42008). Section 3 gives the results of the laboratory testing. Section 4 provides an analysis of the laboratory testing and reconmendations of future work. Section 5 describes the recommended path forward. Section 6 supplies the references used in this document. Copies of the laboratory notebook pages covering the preparation of samples and testing of the detector are maintained in the WRPS Quality Assurance records. 


\section{Summary of the Plan for Evaluation}

The Evaluation Ptan for an In-Situ Vadose Zone Technetium-99 Detector (RPP-ENV-42008) presents the requirements for the laboratory testing of the ${ }^{99} \mathrm{Tc}$ detector. It is summarized in this section.

\subsection{General Approach}

The general approach to evaluale the technetium-99 $\left({ }^{99} \mathrm{Tc}\right)$ detector is to determine how readings from the detector, taken in a labrratory setting, ompare with calibrated point sources and with laboratory analyses of Tank Farm vadose zone samples. Samples were chosen so that the ${ }^{99} \mathrm{Tc}$ concentrations cover a wide range ( $-1101,000 \mathrm{pCi}$ of ${ }^{2 \%} \mathrm{Tc}$ per gram of soil). The distance from the sample face to the detector face will be varies to determine the efficiency of the detector for differences in air distance between the soil and the detector. Finally. different soils will be used to determine the effect of non ${ }^{99} \mathrm{Tc}$ radjation (such as naturally occurring potassium- $40-{ }^{40} \mathrm{~K}$ ) on the results.

Note that for laboratory testing, the detector was positioned with its cylindrical axis horizontal to the laboratory bench surface. The technetium-containing scil was placed in a rectangular tray beneath the detector. Although such a geometry does not provide an accurate calibration for a in-situ environment, it does provide a test of bow well the detector can distinguish between ${ }^{99} \mathrm{Tc}$ and natural background radiation, the effect of the air gap between the detector and the soil, and the effect of thin laboratory samples, whose thickness more closely mimic the effective depth for the vadose zone.

\subsection{Sample Preparation}

Following the requirements of RPP-ENV-42009, the Pacific Nothwest National Laboratory (PNNL) prepared samples. With the concurrence of the WRPS. PNNL selected split-spoon liners previously obtained for WRPS as the source material for the soil samples. The characteristics of the samples are presented in Table 1.

The containers to hold the material are roughly rectangular trays having an inside length of -5 inches, a width of $\sim 3$ inches, and an inside height of $\sim 2.3$ inches. The containers hold $\sim 34.5$ cubic inches ( $565 \mathrm{ml}$ ) and contain $\sim 960$ grams of soil.

The nominal 30. 100. and $500 \mathrm{pCi} / \mathrm{g}{ }^{99} \mathrm{Tc}$ samples were shipped to the Idabo Natjonal Laboratory (INL) and used for the testing. 
Table 1. Vadose Zone Sediments to Be Used to Create Testing Samples

\begin{tabular}{|c|c|c|c|c|c|c|}
\hline & \multicolumn{6}{|c|}{ Desired Tc Concentration (pCi/g) } \\
\hline & $\mathbf{1}$ & 10 & $30^{\mathrm{e}}$ & 100 & $5000^{e}$ & $1000^{e}$ \\
\hline Location & C-105 & C-105 & SX-115 & T-106 & T-106 & T-106 \\
\hline Burehole Number & $(4297$ & C4297 & B8800 & $\mathrm{C} 4104$ & C.4105 & $\mathrm{C} 4105$ \\
\hline Sample II) & $504028 \cdot 37 \mathrm{~A}$ & $504028: 80$ & $\mathrm{~B} \$ \$ 09-25 \mathrm{~A}$ & C4104-22B & $503044.12 \mathrm{~A} / \mathrm{B}$ & $503044.9 \mathrm{~A} / \mathrm{H}$ \\
\hline Depth (ft bgs) & 62.5 & 137 & 100 & 123 & 96.7 & 86.7 \\
\hline Tc-99 (pCi/g) & 1.29 & 8.42 & 27.3 & 113 & 497 & 1050 \\
\hline $\mathrm{K}-40^{\mathrm{e}}(\mathrm{pCi} / \mathrm{g})$ & 11.6 & 14 & 22.3 & 14.3 & 11.5 & 22.3 \\
\hline $\mathrm{C}_{0}-60^{\mathrm{e}}(\mathrm{pCl} / \mathrm{g})$ & $\mathrm{ND}^{\mathrm{a}}$ & $\mathrm{ND}^{\mathbf{4}}$ & $\mathrm{ND}^{\mathrm{a}}$ & $\mathrm{ND}^{\mathrm{in}}$ & 0.555 & 0.453 \\
\hline $\mathrm{Cs}-137^{\mathrm{e}}(\mathrm{pCi} / \mathrm{g})$ & $\mathrm{ND}^{\mathrm{a}}$ & $\mathrm{ND}^{2}$ & $\mathrm{ND}^{\mathrm{a}}$ & $\mathrm{ND}^{\mathrm{a}}$ & 0.039 & 0,028 \\
\hline Th-232 $(p C i / g)$ & $\mathrm{ND}^{\mathrm{a}}$ & $\mathrm{ND}^{n}$ & $\mathrm{ND}^{\mathrm{a}}$ & $\mathrm{ND}^{\mathrm{a}}$ & $\mathrm{ND}^{\alpha}$ & $\mathrm{ND}^{\mathrm{a}}$ \\
\hline $\mathrm{U}=238^{\mathrm{e}}(\mathrm{pCl} / \mathrm{g})$ & $0.122^{\mathrm{c}}$ & $0.213^{\mathrm{c}}$ & $<1$ & $0.13^{\epsilon}$ & 6.58 & $<1.06$ \\
\hline Nitrate (ng/g) & $2.09^{d}$ & $19.5^{d}$ & $424^{d}$ & $112^{\mathrm{d}}$ & $769^{d}$ & $1030^{\mathrm{d}}$ \\
\hline Sodium (ug/g) & $313^{c}$ & $404^{c}$ & $\mathrm{NM}^{\mathrm{b}}$ & $768^{c}$ & $584^{c}$ & $302^{\varsigma}$ \\
\hline $\begin{array}{l}\text { Actual Mass in } \\
\text { Sample (g) }\end{array}$ & 604 & 544 & 484 & 570 & 510 & 357 \\
\hline
\end{tabular}

" "ND" indicates the anjalyte was not detected in the sample.

- "NM" indicates the analyte was not measured in the sample.

"reported data was based on analysis of acid extract sample.

deported data was based on malysis of water extract sample.

${ }^{\circ}$ ithicates sample sent to INL for analysis.

\subsection{Hardware Description}

The hardware used in the testing is shown in Figure 1. The system components used for the testing are identified in Table 2. Photographs of the detector are showu in Figures 2, 3, and 4.

Table 2. MFC System Components

\begin{tabular}{|l|l|l|l|}
\hline Manufacturer & Model No. & Description & Serial No. \\
\hline Saint Gobain & $1.512 \mathrm{BC} 404 / 3 C 444 \mathrm{G} / 1.5-\mathrm{X}$ & Detector & $200-875$ RJ776 \\
\hline ORTEC & 556 & $\begin{array}{l}\text { High Voltage Power } \\
\text { Supply }\end{array}$ & 06219603 \\
\hline ORTEC & 460 & Delay line amplifier & 2802 \\
\hline ORTEC & 552 & Pulse Shape Analysis/SCA & $772-30$ \\
\hline ORTEC & 567 & TAC/SCA & 06221594 \\
\hline Fast Comtec & $7072 \mathrm{~T}$ & Dual ADC & 60756 \\
\hline Fast Comtec & MPA-3 & Dual Parameter MCA & 331 \\
\hline DELL Computer & Precision 940 & Computer & BYNN811 \\
\hline Microsoft & 5.1 & Windows & NA \\
\hline Fast Comtec & MPANT & MPA-3 Analysis software & Version 1.67 \\
\hline Fast Comtec & Server & MPA-3 Server & Version 1.67 \\
\hline
\end{tabular}


Figure 1. Hardware Diagram

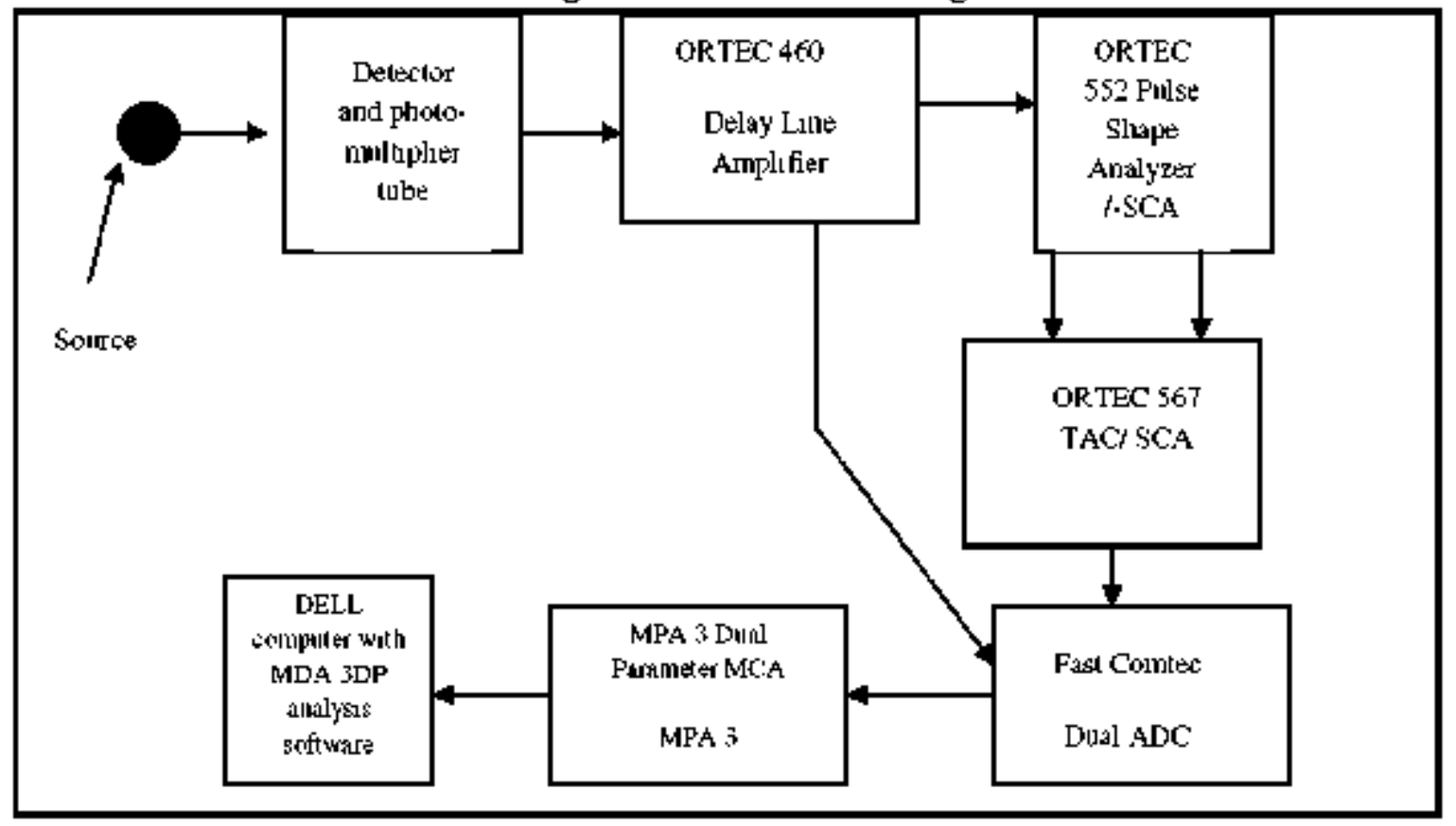

The computer (a standard PC running MPANT Version 1.67 comnercial software under the Microsoft 5.1 Windows Operating System) provided total counts in the inner and outer detectors. No cuts on energy or on coincidences were performed. 
Figure 2. Picture of Probe (1 of 3)

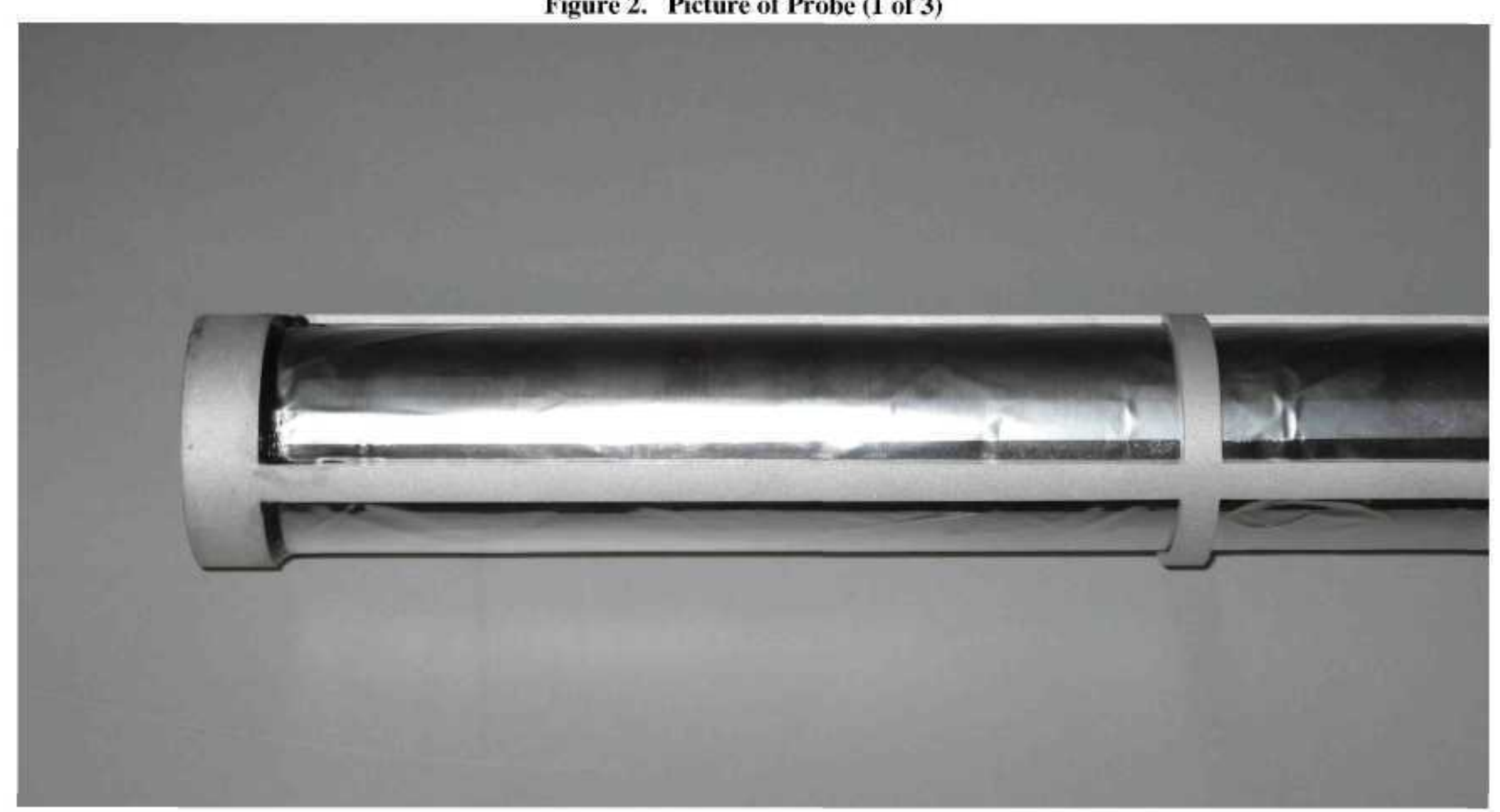


Figure 3. Picture of Probe ( 2 of 3)

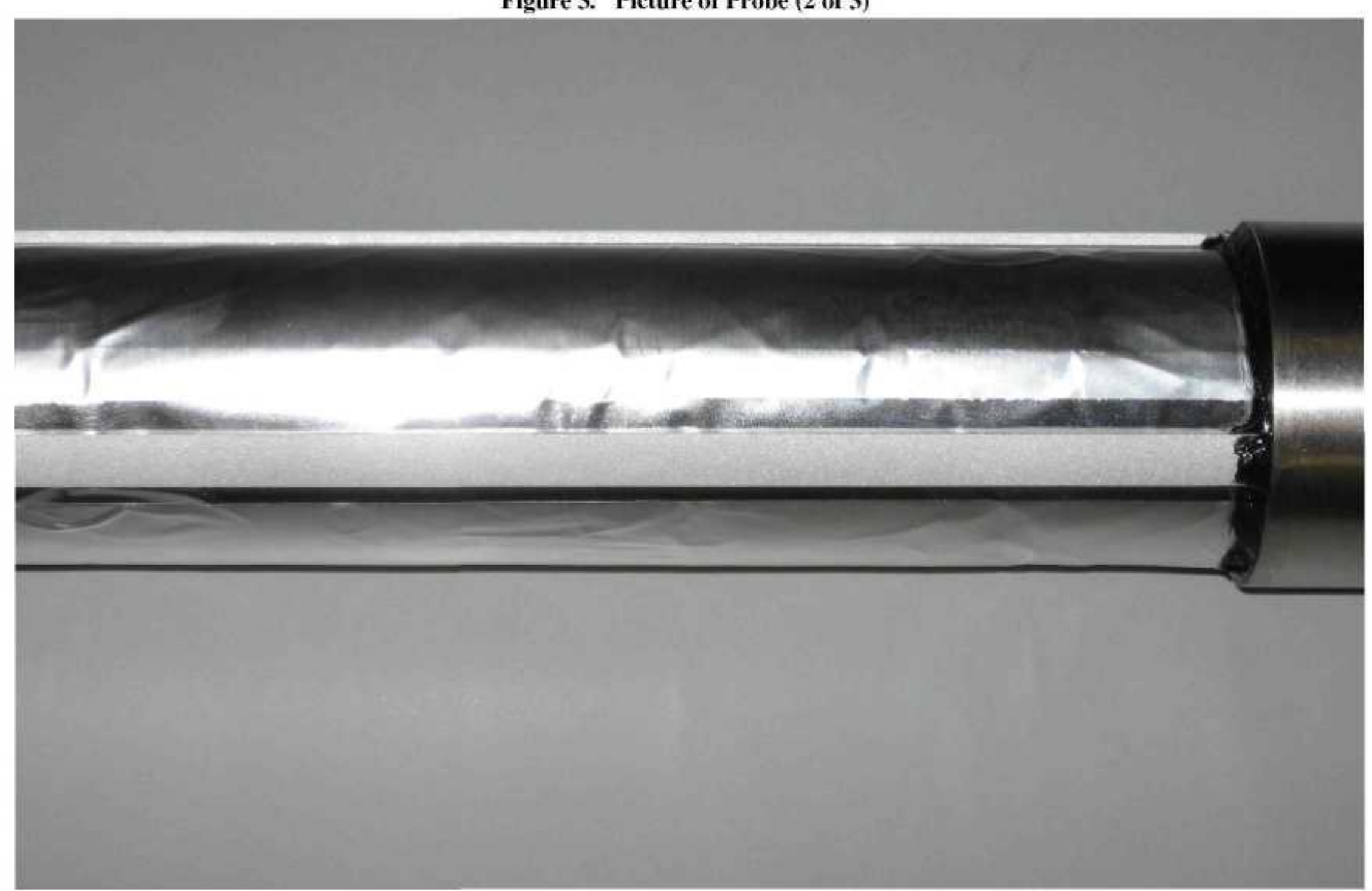


Figure 4. Picture of Probe ( 3 of 3 )

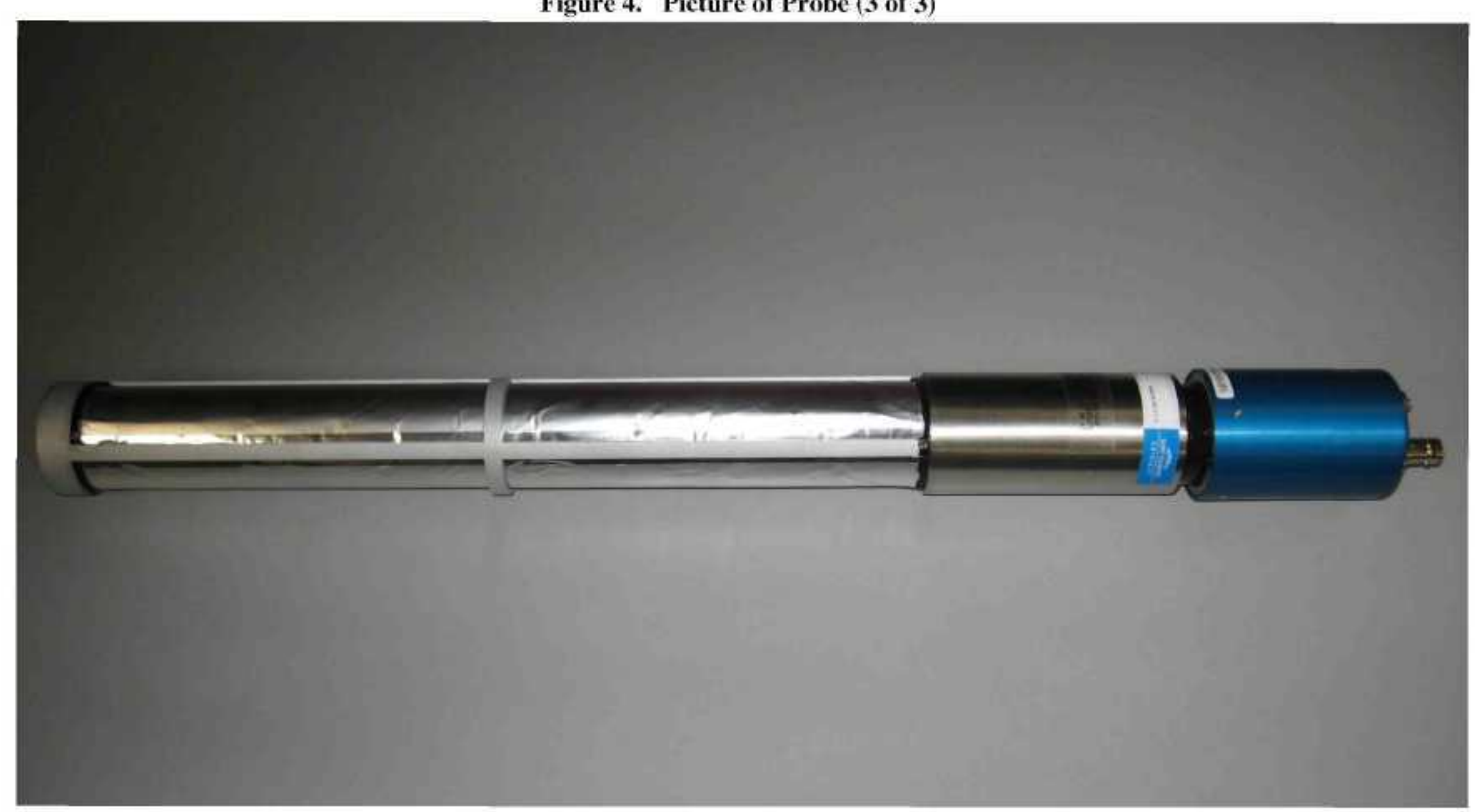




\section{Results of the Tests}

INL received the detector system on August 14, 2009 from Saint Gobain Crystals (12345 Kinsman Road: Newbury, Ohio 44065) and performed acceptance lesting, which was successful. From August 14 through August 24. 2009. INL staff performed functional performance testing of the system. Formal testing, witnessed by Fred Mann, Dave Myers. and Kathi Dunbar of WRPS was conducted on August 26 and 27. 2009. The laboratory notebook used was numbered 1347.

\section{$3.1 \quad{ }^{99}$ Te Point Source Testing}

The testing was performed by Doug Akers (INL) on August 26 at Building IF-638 in Idabo Falls. It was witnessed by Kathi Dunbar, Fred Mann, and Dave Myers (WRPS) as well as by Denis Crass (North Wind Inc). The detector system was placed on a laboratory benchtop. A 100.8 nanoCurie ${ }^{99} \mathrm{Te}$ source was placed source down on top of the detector (in contact with detector) or on an adjustable laboratory stand (for other distances). The ${ }^{\text {v9 }} \mathrm{Tc}$ source is a surface mounted point source. Each counting period was approximately 200 seconds. Table 3 shows the counts for each measurement as the distance between the top of the ${ }^{99} \mathrm{Tc}$ source and the detector side was changed. All counts in the outer detector were attributed to ${ }^{99} \mathrm{Tc}$. The distances between the source and the detector were measured with a rule, but because of the curvature of the detector and the sensitivity of the detector and source, the measurements are approximate. Figure 5 shows the relationship between distance and counts.

Table 3. Results of ${ }^{99}$ Te Point Source Measurements ${ }^{\text {a }}$

\begin{tabular}{|l|l|r|}
\hline $\begin{array}{c}\text { Distance from Source to Detector } \\
\text { Face (inches) }\end{array}$ & Count Time (seconds) & $\begin{array}{c}\text { Number of Conmts } \\
\text { Attributed to" }\end{array}$ \\
\hline 0 & 200.2 & 74.354 \\
\hline$\sim 0.3$ & 200.1 & 42.269 \\
\hline$\sim 0.7$ & 200.1 & 21,707 \\
\hline-1.4 & 200.0 & 13,410 \\
\hline-3 & 200.0 & 5,459 \\
\hline$\sim 6$ & 200.0 & 2,419 \\
\hline No source & 200.0 & 1,614 \\
\hline
\end{tabular}

a Count duration was about 200 seconds. ${ }^{49}$ Te source strength was 100.8 nanoCuries. 


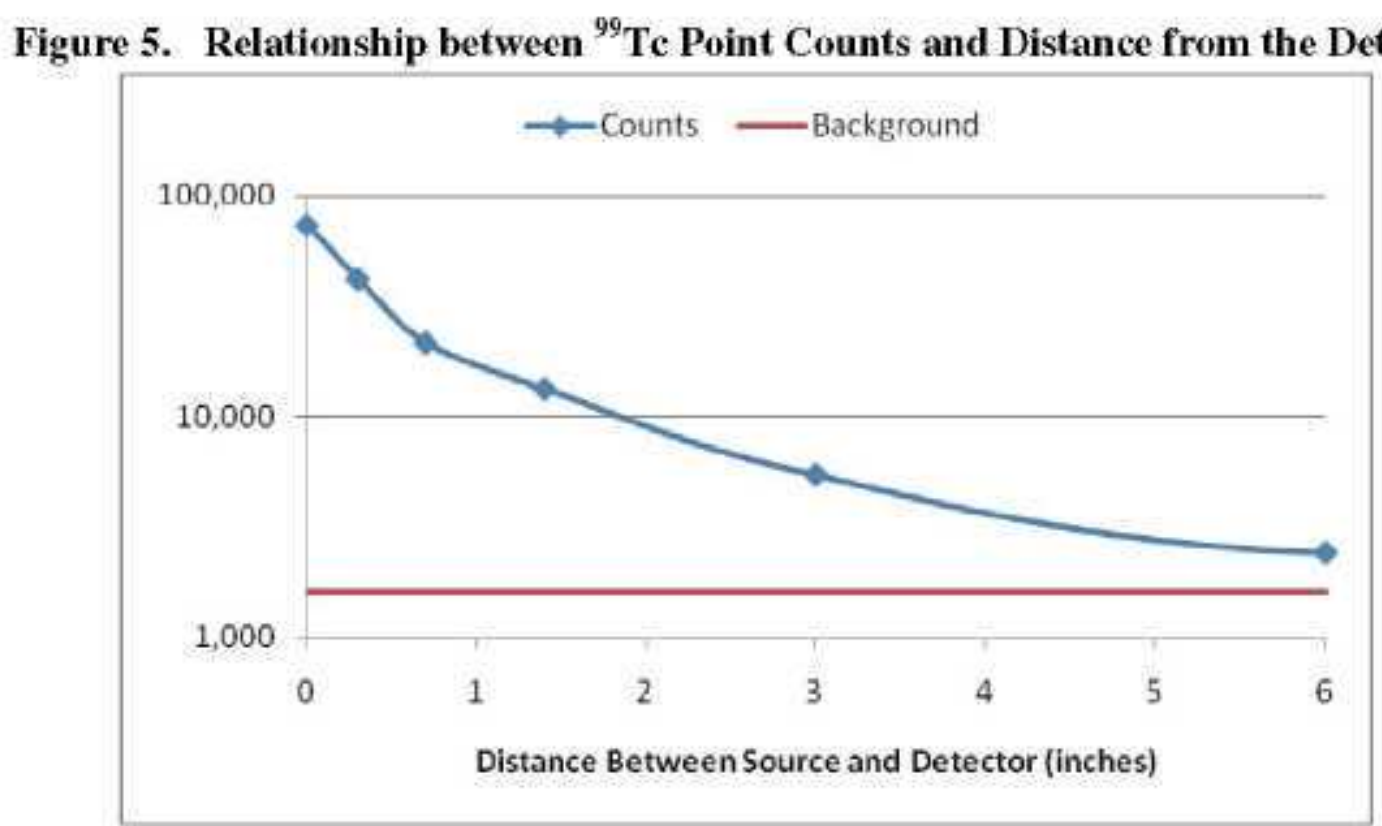

\section{$3.2{ }^{99} \mathrm{Tc}$ Point Source and $30 \mathrm{pCi} / \mathrm{g}$ Soil Sample Testing.}

Given the results of the previous test, the WRPS lead representative decided that this test was not needed. A test with Idaho soil was performed, showing clean separation between the ${ }^{99} \mathrm{Tc}$ peak and the ${ }^{40} \mathrm{~K}$ peak. However, because Idaho soil derives from basalts, while Hanford soil derives from granite (which is higher in ${ }^{40} \mathrm{~K}$ content), actually ${ }^{40} \mathrm{~K}$ interference was evaluated using Hanford supplied soil samples (see Section 3.3).

\subsection{Soil Sample Testing.}

Testing was conducted by Doug Akers (INL) on August 27 at the Materials and Fuels Campus (MFC) of the Idaho National Laboratory. The laboratory room used has significant background. The testing was witnessed by Kathi Dunbar, Fred Mann, and Dave Myers (WRPS) as well as by Denis Crass (North Wind Inc.). The box containing the three soil samples (nominal $30 \mathrm{pCi} / \mathrm{g}$ ${ }^{99} \mathrm{Tc}$, nominal $100 \mathrm{pCi} / \mathrm{g}{ }^{99} \mathrm{Tc}$, and nominal $500 \mathrm{pCi} / \mathrm{g}{ }^{99} \mathrm{Tc}$ ) shipped from PNNL was opened. As shown in Figure 6, the detector was placed on a pair of bismuth shielding blocks to support the detector on its horizontal axis. Each soil sample was placed on an adjustable labjack. Each counting period was about 500 seconds. Table 4 shows the counts for each measurement as the distance between the top of the nominal soil source and the detector side was changed. All counts in the outer detector were attributed to ${ }^{99} \mathrm{Tc}$, while all counts in the inner detector were attributed to ${ }^{40} \mathrm{~K}$. The distances between the source and the detector were measured with a rule, but because of the curvature of the detector and the sensitivity of the detector and source, the measurements are approximate. Figure 7 shows the relationship between distance and counts.

At the end of this sequence of measurements, the detector stopped functioning. That is, no counts were detected. 
Figure 6. Photograph of Soil Sample Counting

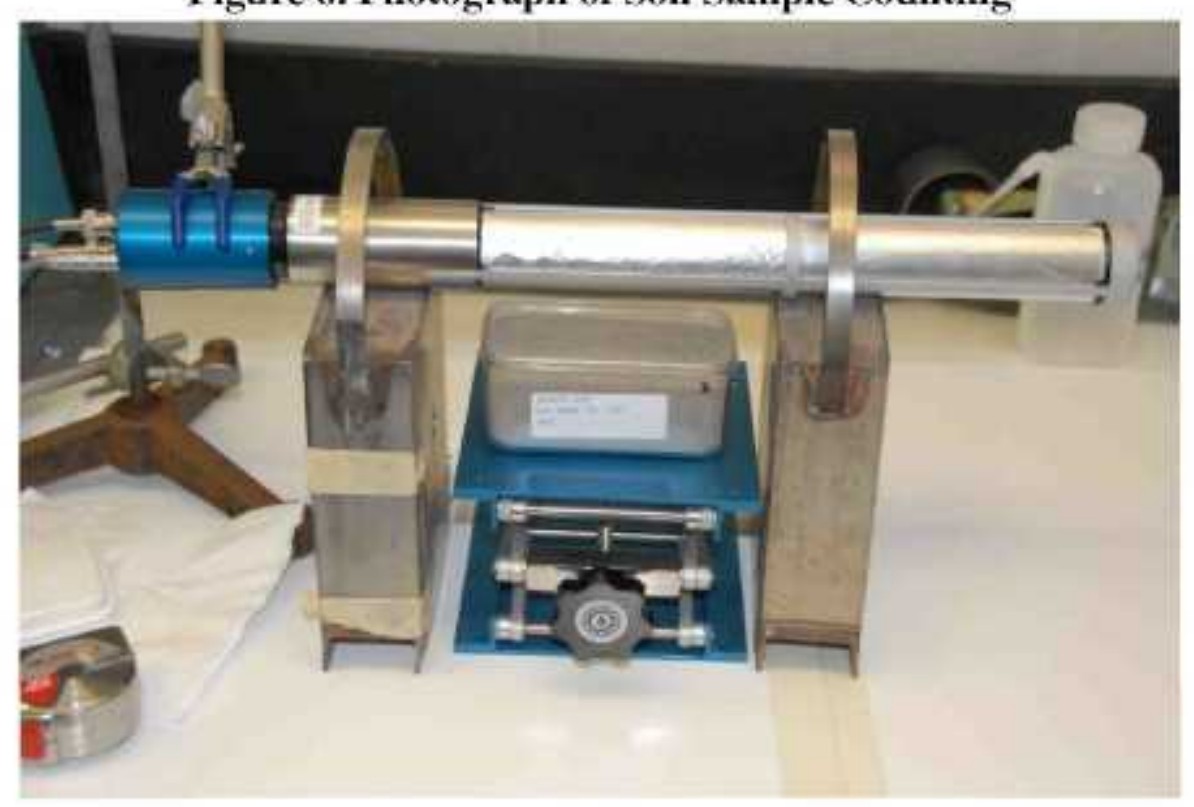

Figure 7a. Relationship between ${ }^{99}$ Te Counts from Soil Samples and Distance from the Detector

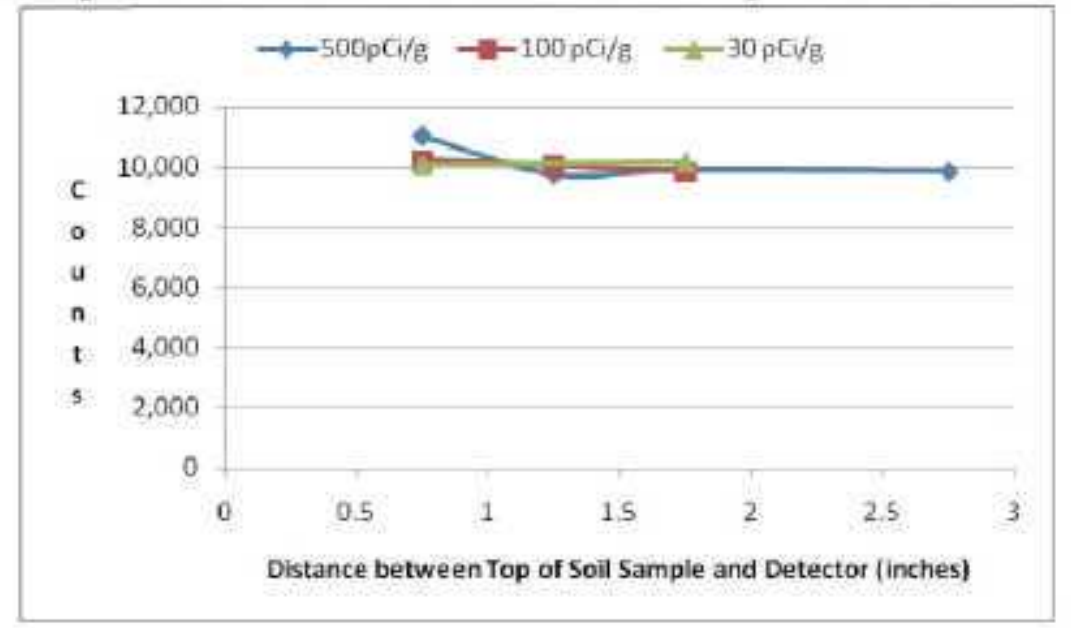


Figure $7 \mathrm{~b}$. Relationship between ${ }^{40} \mathrm{~K}$ Counts from Soil Samples and Distance from the Detector

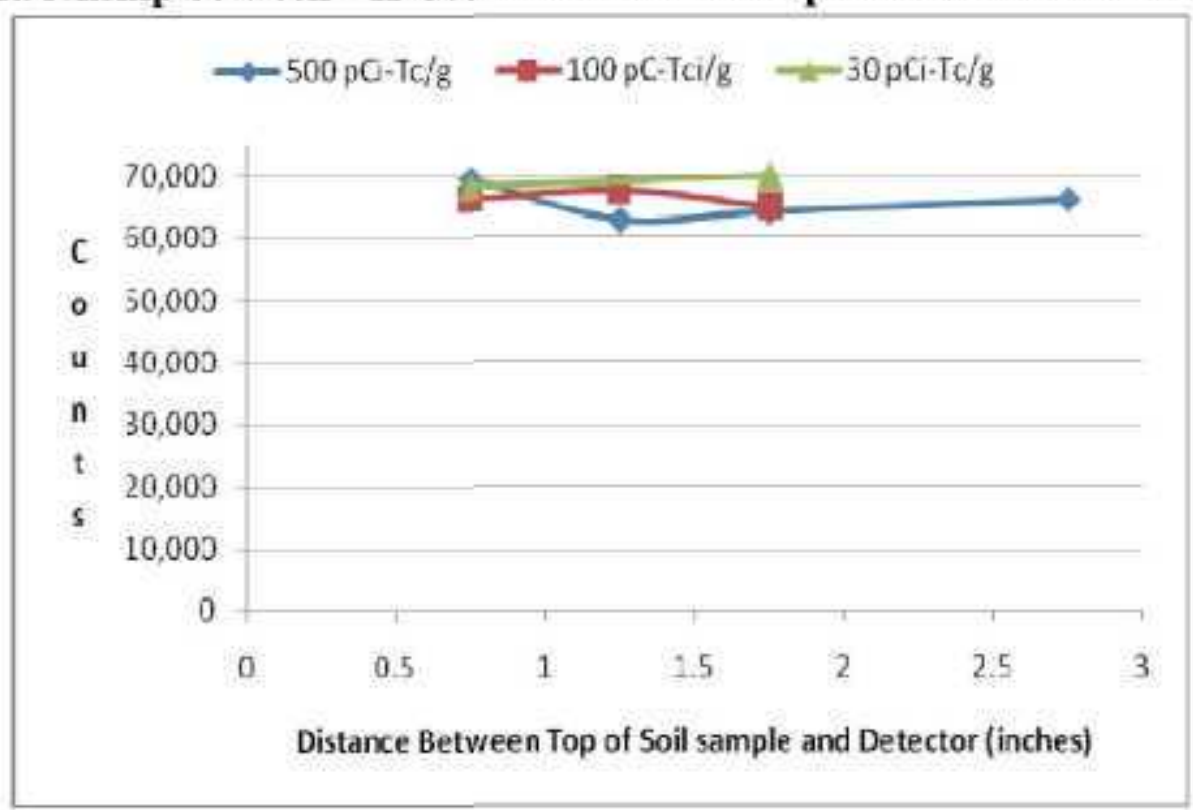

Table 4. Results of Soil Sample Measurements ${ }^{\text {a }}$

\begin{tabular}{|l|r|r|r|r|}
\hline Soil Sample & $\begin{array}{l}\text { Distance from Soil Source } \\
\text { to Detector Face (inches) }\end{array}$ & $\begin{array}{l}\text { Count Duration } \\
\text { (seconds) }\end{array}$ & $\begin{array}{l}\text { Number of Counts } \\
\text { Attributed to }{ }^{\text {99 }} \mathbf{T c}\end{array}$ & $\begin{array}{l}\text { Number of Counts } \\
\text { Attributed to }{ }^{40} \mathbf{K}\end{array}$ \\
\cline { 2 - 5 } & $\sim 0.75$ & 500.3 & 11,018 & 69.529 \\
\cline { 2 - 5 } & $\sim 1.25$ & 500.3 & 9,749 & 62,976 \\
\cline { 2 - 5 } & $\sim 1.75$ & 500.3 & 9,887 & 64,245 \\
\hline $100 \mathrm{pCi} / \mathrm{g}$ & $\sim 2.75$ & 500.3 & 9,845 & 66,265 \\
& $\sim 0.75$ & 500.3 & 10,233 & 66,226 \\
\cline { 2 - 5 } & $\sim 1.25$ & 500.3 & 10,041 & 67,700 \\
\hline $30 \mathrm{pCi} / \mathrm{g}$ & $\sim 1.75$ & 500.3 & 9,835 & 65,007 \\
\cline { 2 - 5 } & $\sim 0.75$ & 500.3 & 10,073 & 68,334 \\
\hline
\end{tabular}




\section{Analysis of the Testing and Recommendations on Future Work}

\subsection{Analysls of the Testing}

\subsection{1 ${ }^{99}$ Te Point Source Testing}

Figure 5 displays the results of the first set of tests (point ${ }^{99} \mathrm{Tc}$ source as a function of space between the source and the detector face). As expected. the detector was most efficient with the point source on the detector. As the size of the air gap increased, the air deflected and slowed down the beta particles (electrons) enitted by the ${ }^{90} \mathrm{Tc}$ source. A distauce of 0.3 iuches reduced the efficiency by a factor of 2 . The detector performed as expected.

\subsection{2 ${ }^{99}$ Te Point Source Testing in the Presence of ${ }^{40} \mathrm{~K}$}

The WRPS lead representative decided that this test as described in Section 3.1.2 was not needed.

\subsubsection{Soil Sample Testing}

The soil sample tests performed on August 27 produced unexpected results. Although the amount of ${ }^{99} \mathrm{Tc}$ in the soil samples was comparable to the $100 \mathrm{nCi}{ }^{99} \mathrm{Tc}$ point source $(300 \mathrm{nCi}$ for the $500 \mathrm{pCi} / \mathrm{g}$ soil sample, $60 \mathrm{nCi}$ for the $100 \mathrm{pCi} / \mathrm{g}$ soil sample, and $18 \mathrm{nCi}$ for the $30 \mathrm{pCi} / \mathrm{g}$ sample), the responses were quite different. Moreover. according to the PNNL analytical results, the ${ }^{40} \mathrm{~K}$ concentration was a factor of 2 higher in the $30 \mathrm{pCi} / \mathrm{g}$ soil sample than in the $500 \mathrm{pCi} / \mathrm{g}$ sample, with the $100 \mathrm{pCi} / \mathrm{g}$ sample having a ${ }^{40} \mathrm{~K}$ concentration in between. However. the results showed a consistent number of counts attributable to ${ }^{40} \mathrm{~K}$. Looking at the displays, there also seemed to be very high background, which was not reduced by shielding blocks.

The day after the WRPS-supervised testing. it was determined that the outer sheath of the detector was not anodized and therefore conductive. Suppoting the detector on the bismuth blocks for the soil sanple tests: i.e., contact between the bisnuth block and detector, created a ground fault in the conductive (ungrounded) detector outer sheath (Figure 6). A photograph (Figure 8) shows a snall crease on the detector surface where it contacted the bismuth block. It is believed that a ground loop had formed, causing the large background observed during the measurements as well as the failure of the detector to detect counts at the end of the August 27 soil tests. 
Figure 8. Photograph of Detector Face after Soil Testing.

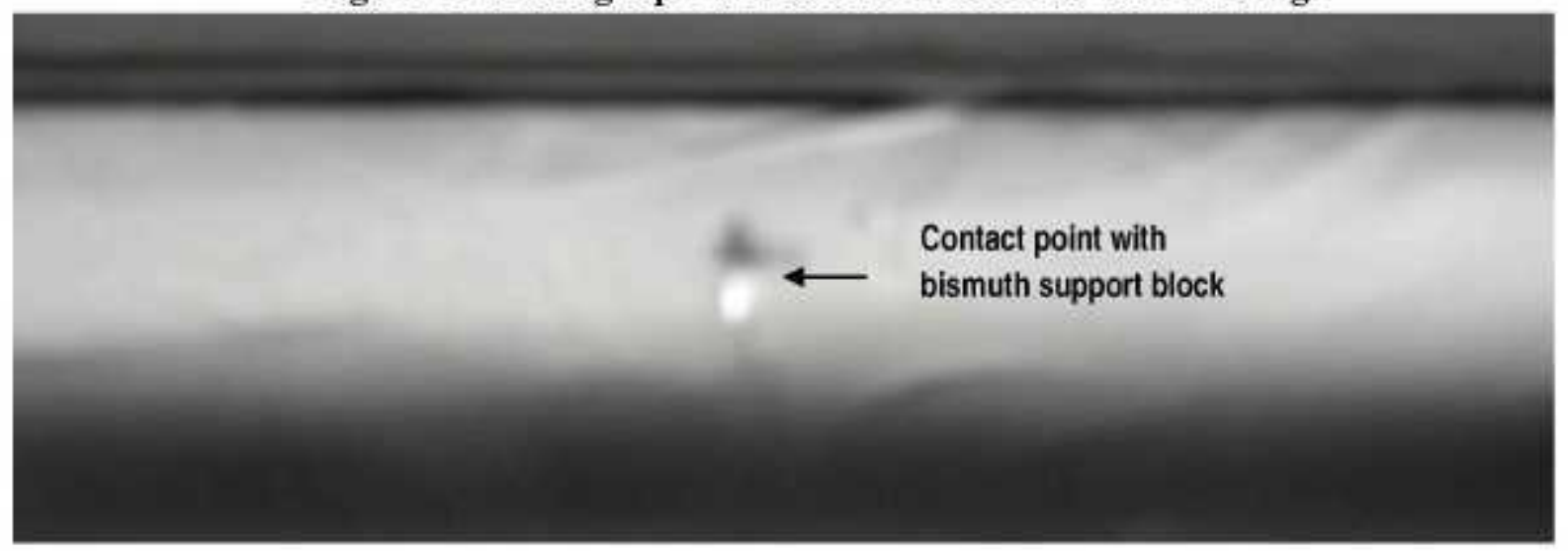

\subsection{Additional Measurements}

On August 28, 2009, Doug Akers repeated the 99Tc point source measurements of August 26. The reproducibility was very good. Based on the assumption that the unsuspected ground loop was the problem, WRPS authorized a repeat of the soil sample measurements.

The soil sample measurements were repeated on September 1, 2009 at the MFC, but in a different room having lower background. This time the measurements also included the point ${ }^{99} \mathrm{Tc}$ source in the presence of the $30 \mathrm{pCi} / \mathrm{g}$ soil sample. The electronics setup was the same as for the previous measurements. Figure 9 shows how the detector and soil sample was held to avoid ground loops. The count time was about 200 seconds. Table 5 shows the results of these experiments as well as the repeat of the soil measurements.

Time responses for the $30 \mathrm{pCi} / \mathrm{g}$ and $500 \mathrm{pCi} / \mathrm{g}$ soil samples at 0.75 inch are shown in Figures 10 and 11. The time responses for the point ${ }^{99} \mathrm{Tc}$ source and the $30 \mathrm{pCi} / \mathrm{g}$ soil sample are shown in Figure 12 , both nominally at 0.75 in from the detector.

Figure 9. Detector and Soil Samples Set-Up for September 1 measurements.

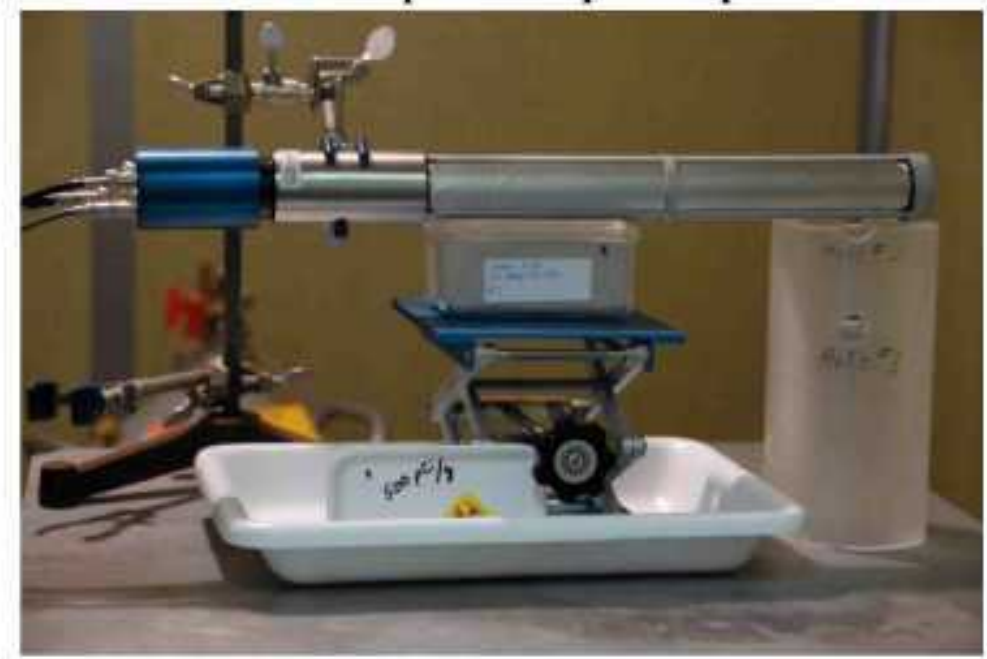


Table 5. Measurements Taken on September 1, 2009.

Coun1 Duration was 200 Seconds)

\begin{tabular}{|c|c|c|c|c|}
\hline Spectrim ID & Description & Soll to detector distance (ln.) & $\begin{array}{c}\text { Outer } \\
\text { Scintillator }\end{array}$ & $\begin{array}{c}\text { Inner } \\
\text { Scintillator }\end{array}$ \\
\hline Bkgd_035 & Background in vault & 0.75 & 191 & 301 \\
\hline Tc-99-D500_036 & $500 \mathrm{pCi} / \mathrm{g}$ soil & 0.75 & 510 & 582 \\
\hline T⿺-99-D500_037 & $500 \mathrm{pCi} / \mathrm{g}$ soil & 1.25 & 476 & 577 \\
\hline Ti Tc-99-D500_038 & $500 \mathrm{pCi} / \mathrm{g}$ soil & 1.75 & 447 & 505 \\
\hline Tс Tc-99-D500_039 & $500 \mathrm{pCi} / \mathrm{g}$ soil & 2.25 & 392 & 461 \\
\hline T: Tc-99-D500_040 & $500 \mathrm{pCi} / \mathrm{g}$ soil & 2.75 & 376 & 480 \\
\hline INL Ditt_041 & Normalized soil blank & 0.75 & 242 & 404 \\
\hline Tc-99-D100_042 & $100 \mathrm{pCi} / \mathrm{g}$ soil & 0.75 & 351 & 491 \\
\hline Tc-99-D100_043 & $100 \mathrm{pCi} / \mathrm{g}$ soil & 1.25 & 312 & 471 \\
\hline Tc-99-D100_044 & $100 \mathrm{pCi} / \mathrm{g}$ soil & 1.75 & 281 & 440 \\
\hline Tc-99-D100_045 & $100 \mathrm{pCi} / \mathrm{g}$ soil & 2.25 & 300 & 411 \\
\hline Tc-99-D30_046 & $30 \mathrm{pCi} / \mathrm{g}$ soil & 0.75 & 427 & 619 \\
\hline Tc-99-D30_047 & $30 \mathrm{pCi} / \mathrm{g}$ soil & 1.25 & 322 & 510 \\
\hline Ti-99-D30_048 & $30 \mathrm{pCi} / \mathrm{g}$ soil & 1.75 & 286 & 466 \\
\hline T\&-99-D30_049 & $30 \mathrm{pCu} / \mathrm{g}$ soil & 2.25 & 251 & 446 \\
\hline Tc-99-D30_050 & $30 \mathrm{pCj} / \mathrm{g}$ soil w/o ${ }^{9 y} \mathrm{Tc}$ source & 0.75 & 374 & 514 \\
\hline Tc-99-D30_051 & $30 \mathrm{pCi} / \mathrm{g}$ soil w/ ${ }^{0,9} \mathrm{Tc}$ source at $0.25 \mathrm{in}$ & 0.25 & 2323 & 575 \\
\hline Tc-99-D30_052 & $30 \mathrm{pC} / \mathrm{j} / \mathrm{s}$ soll w/ ${ }^{99} \mathrm{Tc}$ source at $0.75 \mathrm{in}$ & 0.75 & 1236 & 594 \\
\hline Tc-99-D30_053 & $30 \mathrm{RC} / \mathrm{g}$ soil w $/{ }^{\mathrm{gy}} \mathrm{Tc}$ source at $1.5 \mathrm{in}$ & 1.50 & 1072 & 625 \\
\hline Tc-99-D30_054 & $30 \mathrm{pCi} / \mathrm{g}$ soil w/ ${ }^{\mathrm{gg}} \mathrm{Tc}$ source at $1.75 \mathrm{in}$ & 1.75 & 1578 & 544 \\
\hline
\end{tabular}




\section{RPP-ENV-42667, Rev. 0}

Figure 10. Time Responses for the 30pCi/g Soil Sample

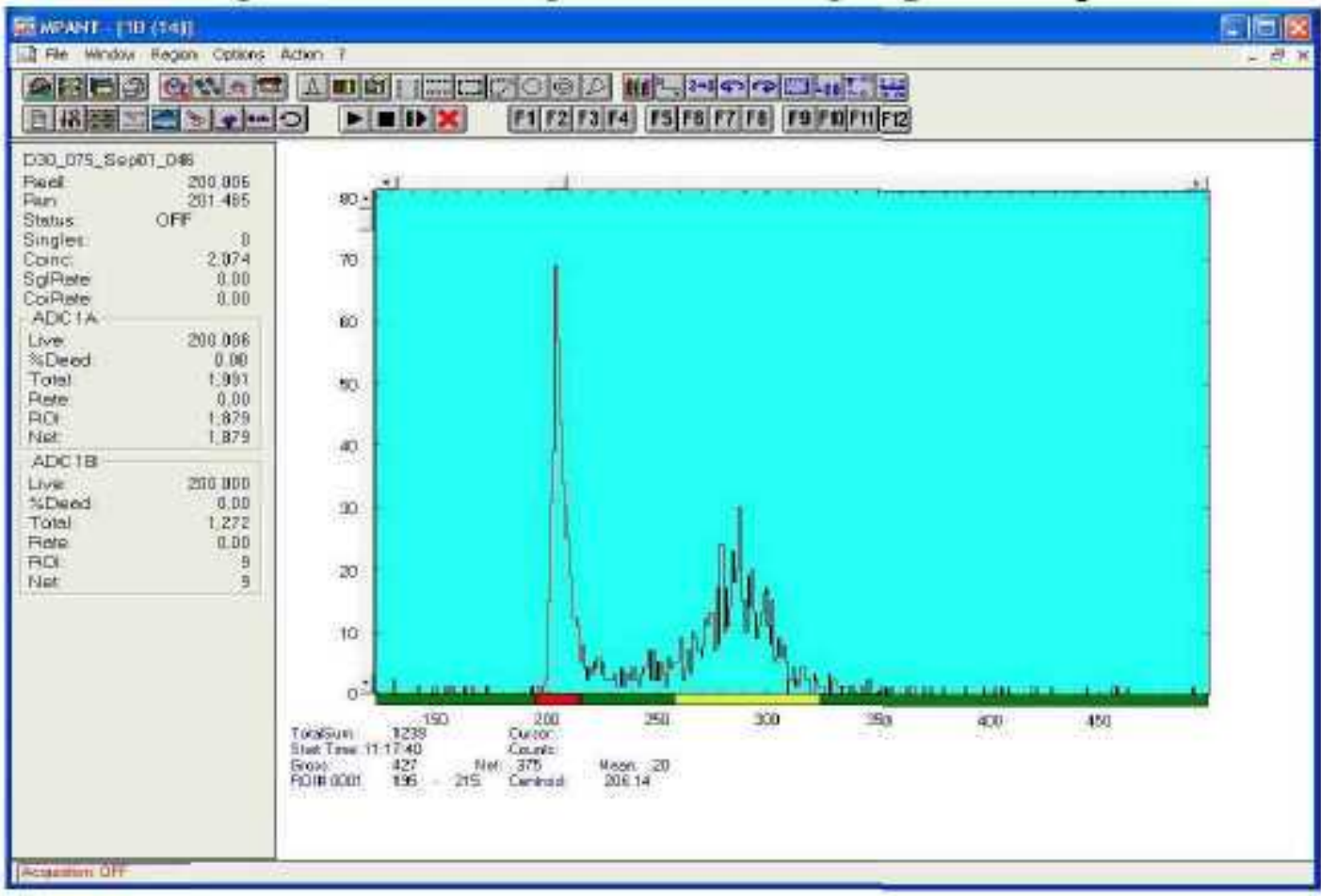

Figure 11. Time Responses for the 500pCi/g Soil Sample

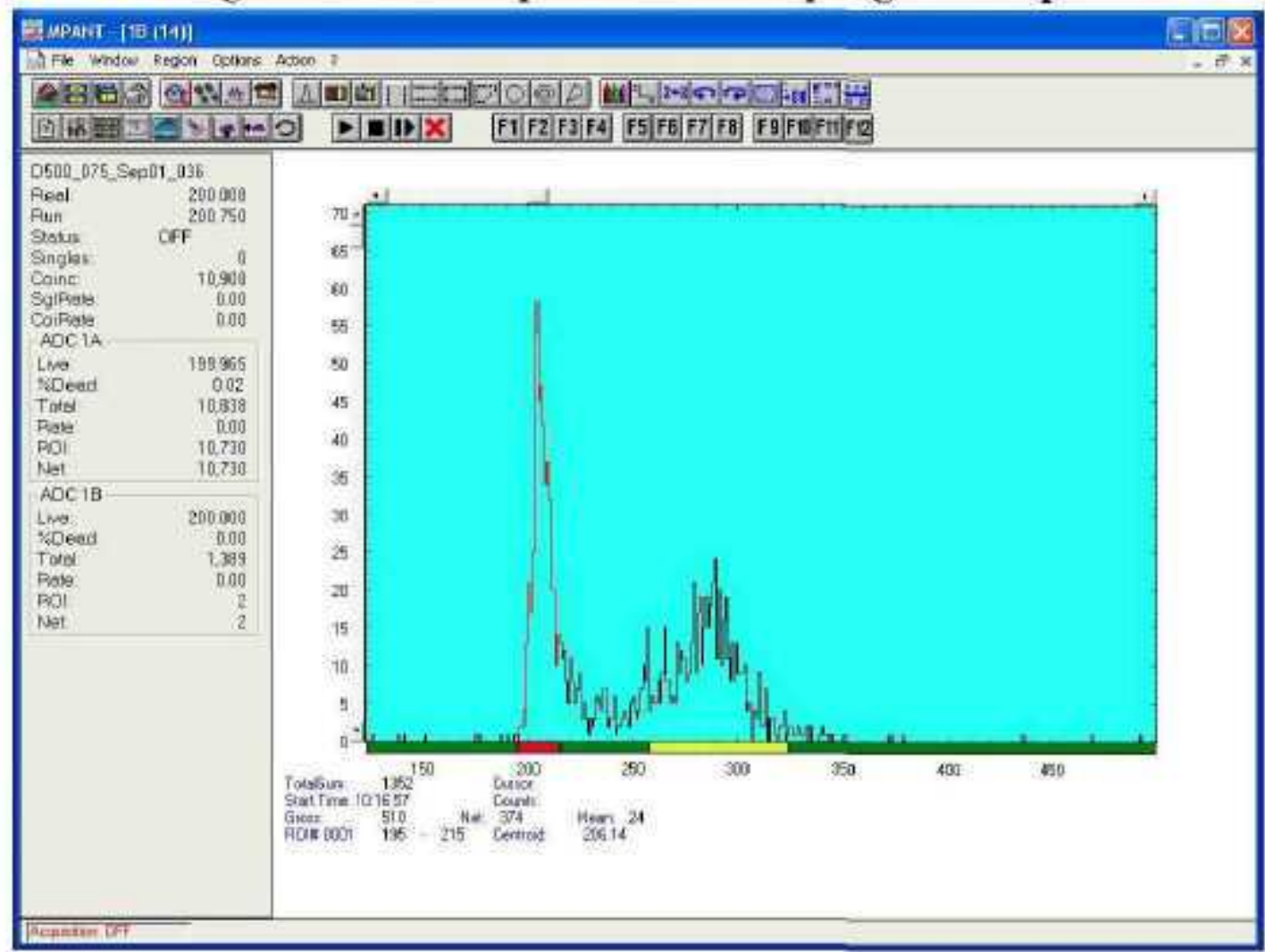


Figure 12. Time Responses for the $30 \mathrm{pCi} / \mathrm{g}$ Soil Sample and Point ${ }^{99} \mathrm{Tc}$ Sample

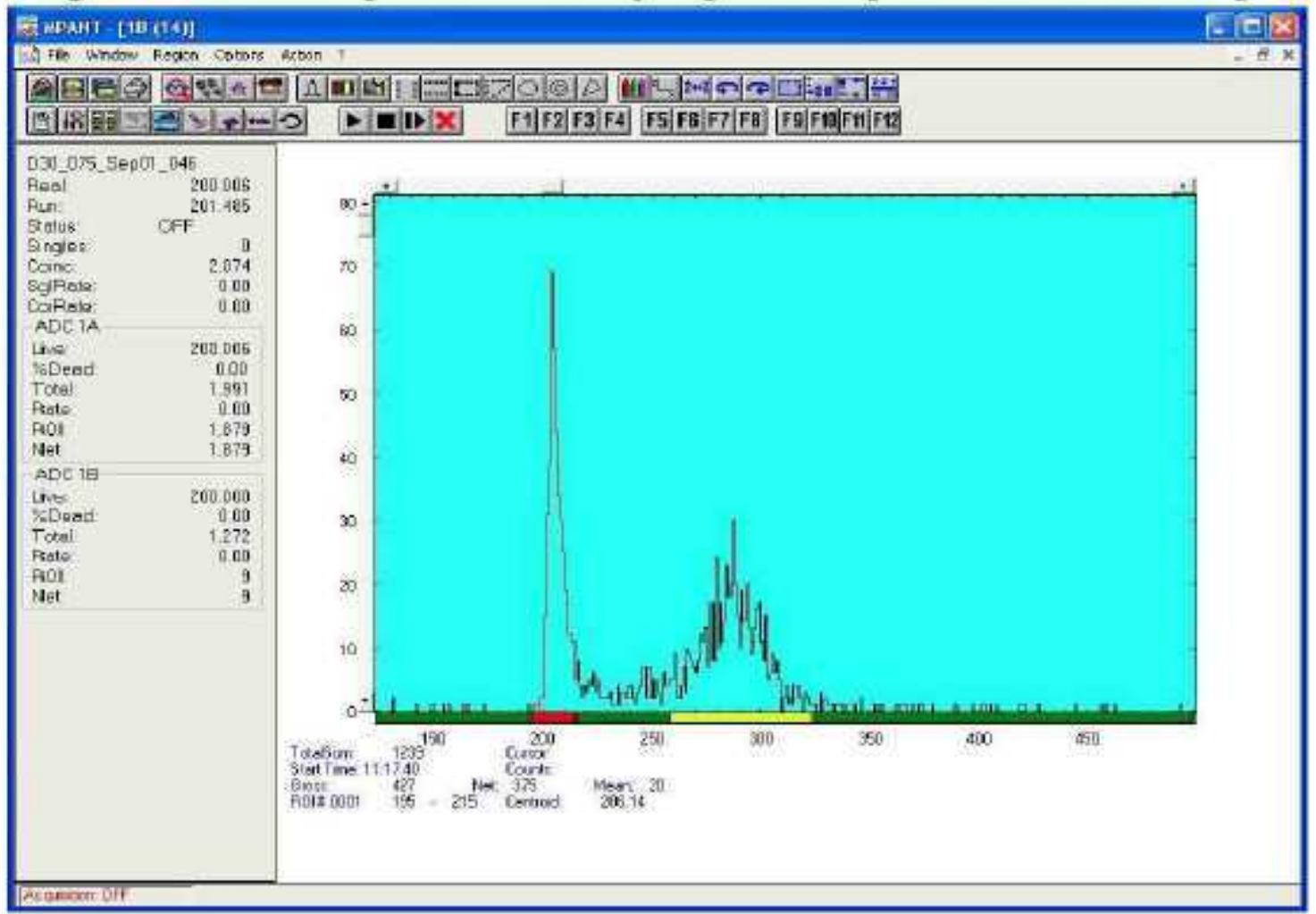

\subsection{Observations of Additional Measurements}

The following observations are central to the analysis:

- High background

- Repeatability

- Sensitivity

- Understanding the system

The room where the soil sample measurements were made had a high background (191 counts in 200 seconds in the outer detector and 301 counts in the inner detector) compared to 351 counts in the outer detector and 491 counts in the inner detector for the same time period for the $30 \mathrm{pCi} / \mathrm{g}$ soil sample 0.75 inches from the detector. Thus, a large fraction of the counts were simply from room background. Because of the short range of beta particles, all of this background is probably gamma radiation. Thus, further laboratory testing should be performed in an environment having very low background.

One measurement was repeated, $30 \mathrm{pCi} / \mathrm{g}$ soil at 0.75 inch from the detector (identification labels $=\mathrm{T} c-99-\mathrm{D} 30 \_046$ and $\mathrm{Tc}-99-\mathrm{D} 30 \_050$ ). The ratios of the measurements are 1.17 \pm 0.08 and $1.20 \pm 0.07$ for the outer and inner detectors respectively. The small departures from unity are most likely explained by having the soil sample at two slightly different distances from the 
detector in the two cases. As shown in Figure 5, the efficiency of the detector is sensitive to this distance and for the pupose of these tests precise distance measurements were not required. Thus, for future laboratory testing the distance should be fixed and not changed during soil sample replacement. Furthermore, a limitation (although not serious) of any in-situ detector system will be the amount of the air gap between the detector and the soil.

Approximately 10 percent of the detector area was exposed to the soil, the detector having been sized for actual field operation. The counts per $\mathrm{pCi} / \mathrm{g}$ of soil in a 200 second measurement can be estimated by subtracting the counts from the $30 \mathrm{pCi} / \mathrm{g}$ and $100 \mathrm{pCi} / \mathrm{g}$ soil samples from the $500 \mathrm{FCi} / \mathrm{g}$ scil sample. resulting in $0.21 \pm 0.08(100 \mathrm{FCi} / \mathrm{g}$ base) to $0.34 \pm 0.9(30 \mathrm{FCi} / \mathrm{g}$ base $)$ counts per $\mathrm{pCi} / \mathrm{g}$ of soil in 200 seconds. These estimates are slightly low because sone of the count can be ascribed to the higher ${ }^{40} \mathrm{~K}$ in the $100 \mathrm{pCi} / \mathrm{g}$ soil sample (24\% higher) and $10 \mathrm{pCi} / \mathrm{g}$ soil sample (94\% higher). Thus, in a 200 second count, one would expect 2 to 3 counts for 30 $\mathrm{pCi} / \mathrm{g}$ of soil for this configuration. Assuming the entire detector surface could be uset, the total counts in a 200 second measurement would only be 20 to 30 counts. Also, it is expected that the distance between the soil and the deteclor will be closer than 0.75 inches, gain another factor of efficiency (perhaps a factor of 4). Thus, the ability to see such levels is based on decreasing the amount of background caused by ${ }^{46} \mathrm{~K}$ beta. Using the current detector system, the easiest way to perform this is to veto connts in the outer detector if a count in the inmer detector is detected (say within 20 microseconds). Given the lower count rate observed for the $30 \mathrm{pCig}$ soil at 0.75 inches from the detector $(-5$ per second), such coincident requirements are straight forward.

Note that a much more accurate analysis of the sensitivity can be performed knowing the concentrations of the ${ }^{10} \mathrm{~K}$ and ${ }^{99} \mathrm{Tc}$ in the soil samples. However, for this evaluation such an analysis is not warranted as it is clear from the testing performed that while the delector system has very large potential, further development is needed. The room background run shows that for every three counts in the inner detector. only 2 counts are seen in the inner detector. However. for a strong high energy beta source (e.g., the $500 \mathrm{pCi} / \mathrm{g}$ soil sample) the ratio of counts of the inner detector to the outer detector is $0.88 \pm 0.12$ (at 0.75 inches) and $0.97 \pm 0.14$ (at 1.25 inches). However, for further development of this detector system, a good understanding of the detector system is cructal. Furthermore, understanding the degradation of the ${ }^{90} \mathrm{Tc}$ beta spectrum through the air gap and soil will be important in sizing the dimensions of the detector and setting the energy cuts.

One further observation for field deployment should be noted. For laboratory tests, the count rate, as stated above, is quite low. However, there will be areas where the ${ }^{137} \mathrm{Cs}$ soil concentration will be quite high. Provisions should be made to eliminate the power to the photomultiplier tube whenever the count rates exceed some level $(-1,000$ counts per second) in order to save the photonultiplier tube. 


\section{RPP-ENV-42667. Rev, 0}

\subsection{Recommendations for Future Work}

The detector system performs adequately for high technetiun concentration. More developnent and laboratory testing of the current proof-of-concept system is needed before field demonstration is performed. A new detector should be designed and procured for a field demonstration. A laboratory demonstration at the Hanford Site should immediately precede the field demonstration so that DOE's Office of River Protection and Washington State Department of Ecology s1affs can observe the detector perfornauce in a controlled environnent. 


\section{RPP-ENV-42667. Rev, 0}

\section{Recommended Path Forward}

This section presents the future activities for the ${ }^{99} \mathrm{Tc}$ detector development and field testing:

- Further testing at INL using the current detector system (Section 5.1)

- Discussions with Hanford Site staff on needed requirements for field testing and deployment (Section 5.2)

- Development and testing of new ${ }^{49} \mathrm{Tc}$ prototype detector system(s) (Section 5.3)

- Development of a field deployable detector system (Section 5.4)

- Laboratory and field testing of an integrated ruggedized down-hole detector system at the Hauford Site (Section 5,5).

Section 5.6 presents a rough order magnitude (ROM) schedule and cost estimate for these activities. Note that these activities are not currently included in the near term baseline, and will be pursued only following formal DOE approval through a baseline change request process.

\subsection{Further testing at INL using the current detector system}

The electronics used in the current laboratory testing are unsophisticated. However, given the time between delector acceptance and WRPS-supervised testing, little effort was given to the software cut selection and the methods for ${ }^{40} \mathrm{~K}$ and background subtractions. No effort was expended to use coincidence information in the analysis. Optimizing data collection and analysis methods should contribute to futther reducing the minimum detection level for ${ }^{99} \mathrm{Tc}$. Therefore. it is proposed to have PNNL ship the nominal 1. 10 . and $1000 \mathrm{pCi} / \mathrm{g}{ }^{99} \mathrm{Tc}$ soil samples to INL. INL would use these and the soil samples they already have (noninal 30,100 , and $500 \mathrm{pCi} / \mathrm{g}$ ) to optimize the associated electronics and better determiue the sensitivity of the detector.

The emphasis of the testing should be on improving the signal to noise ratio for ${ }^{99} \mathrm{Tc}$ and on understanding the response of the detector system to varying amounts of ${ }^{99} \mathrm{Tc}$ and ${ }^{40} \mathrm{~K}$.

Deliverable: At the end of this activity, the Detector Contractor will send to WRPS a letter report describing the testing and optimization of the detector system as well as lessons learned, including limitations of the system in the presence of non- ${ }^{40} \mathrm{~K}$ beta sources.

\subsection{Discussions with Hanford Site staff on needed requirements for fifeld testing and deployment}

The Hanford Site and tank farms in particular have stringent requirements for the use and release of instruments. Discussions should be held with

- Field work supervisors

- Industrial health

- Radiation Control

- Operators

- Electricians, 
- Other Hanford Site Prime Contractors (particularly the Plateau Remediation Contractor and the Pacific Northwest National Laboratory),

- Other geophysical contractors. and

- Others.

The purpose of these discussions will be to establish the necessary requirements for

1) a fully functional and integrated down-hole delection system.

2) entry and release of instruments in tank farms and the 222-S laboratory, and

3) minimum requirements for conducting field and laboratory demonstrations at Hanford site facilities.

These requirements are to be established before the final de sign of the field deployable detector (Section 5.4).

Based on initial discussions, WRPS will develop straw man discussion points for a 2-day meeting of the interested parties. The Detector Contractor will particjpate in this meeting.

Deliverable: WRPS will issue a formal report on the requirements for a field deployable in-situ vadose zone detector for technetium-99.

\subsection{Development and testing of a new "Tc prototype detector system}

Preliminary testing by INL showed that the initial prototype detector requires some design improvements. At a ninimum these include:

- Light scattering inside the detector

- Coupling between the inner and outer detector.

Based on the INL prelininary measurements using the point ${ }^{99} \mathrm{~T} c$ source as a function of distance from the photomultiplier tube (PMT), a drop off in efficiency (about a factor of 2 ) occurs when the point source is near the PMT versus when the source is at the other end of the detector. Thus, efficiency may be improved by using a PMT at each end of the detector. This would conplicate the design. data collection, and analysis. However. the inprovement in efficiency may be worth the conplexity.

Based on the INL prelininary measurements using the point ${ }^{99} \mathrm{Tc}$ source at different locations on the detector's surface, different efficiencies were noled. Since the detector is nominally symmetric. these differences are likely a reflection of different coupling between the inner and outer detectors. This is not sutprising as the creation of this coupling was changed duriug the manufacture process. As this detector was a first of a kind, such difficulties were expected.

Thus, development of another prototype detector is suggested to optimize shape, length and thickness of the outer detector. Design should start before the measurements on the initial prototype are completed (as much of the testing using the initial is focused on the optimization of the electrouics outside of the detector). 
Again, an inportant emphasis is improving the signal to noise ratio for ${ }^{99} \mathrm{Tc}$ and on understanding the response of the detector system to varying amounts of ${ }^{94} \mathrm{Tc}$ and ${ }^{40} \mathrm{~K}$.

Deliverables: Before procurement of the vew prototype detector, the Detector Contractor will supply to WRPS the goals and proposed test plan for the new prototype detector. A1 the end of activity, the Detector Contractor will send to WRPS a letter report describing the testing and optimization of the detector system as well as lessons learned.

\subsection{Development of a field deployable detector system}

Based on the infornation learned from further testing of the new system (Section 5.1), the rejuirements for deployment at the Hanford Site (Section 5.2), and the testing of a second prototype detector, a ruggedized aew detector for Hanford Site field testing in a direct push probe hole would be developed. Work scope associated with this activity will also include developnent of all necessary ancillary hardware, analytical software, software validation, data management and control processes, and required field procedures to deploy and fully demonstrate an integrated rugsedized ${ }^{99} \mathrm{Tc}$ vadose zone detector system. Note that a fully integrated ruggedized ${ }^{99} \mathrm{Tc}$ vadose zone detector system includes

1) all detector components (e.g. detector scintillators. voltage divider, photomultiplier tube),

2) required analytical software and hardware,

3) all ancillary support equipnent such as deployment mechanisms, unbilical management systems, and

4) necessary $\mathrm{QA} / \mathrm{QC}$ to verify and validate analytical software and results.

Deliverable: The Detector Contractor will transport to the Hanford Site a detector system ready for laboratory and in-situ vadose zone field testing. The detector system will meet all requirements identified in the requirements docunent created above (Section 5.2). The Detector Contractor will seud a WRPS a letter report describing the design, testing. and optimization of the detector system as well as lessons learned.

5.5 Laboratory and field testing of a field deployable detector system at the Hanford Site Using the 3 remainiug soil samples being stored at PNNL (noninally 30.100 aud $500 \mathrm{pCi} / \mathrm{g}$ of ${ }^{94} \mathrm{Tc}$, the soil sampling test would be repeated using the field deployable detector. Such testing would allow staff for DOE's Office of River Protection and from the Washington Department of Ecology to observe testing of the vadose zone deployable detector in a controlled setting. Such testing would also provide infornation on count times needed in an in-situ vadose zone environment. Given the background and space issue identified at the 222-S Laboratories, this demonstration laboratory test should be performed at PNNL. Nole that during the discussions with Hanford site staff requirements will be developed for testing and demonstration of equipment in Hanford laboratory facilities. 
Field testing is anticipated to be accomplished through currently available direct push casing. Two elements are needed to optimize the test:

1. A range of ${ }^{1 / 0} \mathrm{Tc}$ activities over a reasonable depth in the vadose zone; and

2. Ease of access to the test site, by all parties.

Tank farms, due to the numerous restrictions on access. does not provide the optimal site for the initial field demonstration of the ${ }^{99} \mathrm{Tc}$ detector. Although the tank fatms provide an environment where a wide range of ${ }^{99} \mathrm{Tc}$ activity is present throughout the vadose zone, the challenges of gaining farm access by uon-Tank Farm personnel may be sufficient to remove them as preferred initial sites.

Outside the tank farm environment. one Hanford location, the BC Cribs and Trenches Site, provides a range of known ${ }^{99} \mathrm{Tc}$ activity dispersed vertically within the vadose zone. Technetium- 99 activity ranges from less than detectable to as high as $145 \mathrm{pCi} / \mathrm{g}$ in borehole C5923 (Serne et. al., 2009). This borehole is associated with a deep yadose zone remediation experiment being conducted by the Plateau Remediation Contractor (PRC). The borehole exhibits two zones of elevated ${ }^{99} \mathrm{Tc}$, an upper zone ranging from $+28 \mathrm{ft}$ below ground surface (bgs) to $-166 \mathrm{ft}$ bs, and a lower zone ranging from $-210 \mathrm{ft}$ bgs to $246 \mathrm{ft}$ bgs. The vpper zone is the subject of the remediation experiment/demonstration. Table 6. from Serne et.al., provides a distribution of ${ }^{99} \mathrm{Tc}$ in this region. A position adjacent to borehole $\mathrm{C} 5923$ or abother equivalent borehole nearby (such as C5924 and C7047) is proposed for testing of the prototype down-hole ${ }^{94} \mathrm{Tc}$ detector. There is no intent to interfere with the on-yoing deep vadose desiccation experiment that uses Borehole C5923.

The test design of the down-hole demonstration of the ${ }^{99} \mathrm{Tc}$ detector will be such that it parallels how such a system will be typically deployed in a tank farm enyironment. An initial direct push will be made to a 115 toot depth. This hole will be logged for moisture content distribution and gamma emitters using a bismuth-germanium oxide probe. As this borehole is decommissioned, the prototype ${ }^{99} \mathrm{Tc}$ detector will be deployed at nominally $\mathrm{I} \mathrm{ft}$ intervals. Following analysis of the noisture, gamma and ${ }^{99} \mathrm{Tc}$ logs. a decision will be nade on whether or not to proceed with sampling of selected vadose zone horizons. This decision will be made jointly with representatives of the deep yadose zone remediation project to ascertain where samples should be collected.

Should sampling be deemed appropriate: sample depths will be determined and a second direct push initiated to collect samples from the selected depths. Analysis of the sanjples would then be conducted.

Deliverable: WRPS will issue a report describing the results of the laboratory and field testing along with a recommendation on whether or not to deploy the detector as part of the Tank Farm vadose zone chasacterization activities. 
RPP-ENV-42667, Rev. 0

\begin{tabular}{|c|c|c|c|c|c|}
\hline HFIS \# & $\begin{array}{l}\text { mid depth } \\
\text { ti bgs }\end{array}$ & $\begin{array}{c}\text { Tedunetium } 99 \\
\text { porig }\end{array}$ & HEIS $\%$ & $\begin{array}{l}\text { mid depth } \\
\text { ft bges }\end{array}$ & $\begin{array}{c}\text { Technetuma-s9 } \\
\text { PCig }\end{array}$ \\
\hline BIT740 & 5.5 & 0424 & BIT793 & 173 & 0.424 \\
\hline BII74! & 8 & -0.424 & BITOL 6 & 176.8 & 0.424 \\
\hline BIT?A3 & 13 & $0-424$ & BITOL7 & 179.3 & 0.424 \\
\hline BIT24 & 15.5 & 0.424 & B1T9L8 & 1818 & 40.424 \\
\hline B1T745 & 18 & -0.424 & BITOLO & 1843 & 0.424 \\
\hline BIT746 & 205 & -0.424 & B1T708 & 1955 & 0.43 \\
\hline В11816 & 205 & 0.424 & BITB- & 210.5 & $\$ 500$ \\
\hline BlT?4 & 23 & 0.424 & B31786 & 2155 & 13087 \\
\hline B1T74 & 25.5 & $\infty 0424$ & $\mathrm{BITC2}$ & $23 \pi 5$ & $\$ 247$ \\
\hline BII749 & 28 & 723 & В1T\%K6 & 236.8 & 71.19 \\
\hline BII750 & 305 & 482 & BIT9K? & 2393 & 50.81 \\
\hline B1T751 & 33 & 0.59 & B!T9K8 & $2+18$ & 38.88 \\
\hline BITR25 & 368 & 72.14 & BIT824 & 244.3 & 24.16 \\
\hline B1T826. & 393 & $1+37$ & BITVC4: & 2455 & 1471 \\
\hline BIT828 & 43 & 226 & B:T7C9 & 258 & 0.55 \\
\hline BIT752 & 455 & 145.85 & BIT7DI & 263 & 40.424 \\
\hline B1T753 & 48 & 9357 & $B 177 D 8$ & 2805 & (0). 424 \\
\hline BIT755 & 33 & 3380 & BITF1. & 29015 & $<0.424$ \\
\hline $\mathrm{B} 11757$ & 58 & 46.7 & B!17H & 313 & 0.424 \\
\hline BHI763 & 73 & 71.66 & BIT72 & $3+115$ & 8.424 \\
\hline B1T766 & 80.5 & 93.25 & B]V 530 & $3+4$ & 0.388 \\
\hline B11768 & 83 & 54.08 & BIV531 & 340.5 & $-10,388$ \\
\hline BITRI? & 87 & 4385 & BJVर32 & 349 & 0.388 \\
\hline B1T985 & 893 & 6015 & B]V\{33 & 3515 & $<0.388$ \\
\hline В1T768 & 905 & 74.75 & & & \\
\hline B11771 & 98 & 3430 & & & \\
\hline $\mathrm{B} 11773$ & 103 & 28.10 & & & \\
\hline B!T9K9 & 100.5 & 26.85 & & & \\
\hline BITYL0 & 1093 3 & 4.54 & & & \\
\hline BITYLI & 1143 & 2013 & & & \\
\hline BเT7า & 123 & 63.31 & & & \\
\hline B1T818 & 123 & 5688 & & & \\
\hline BITYL? & 1268 & 66.173 & & & \\
\hline BIT9L3 & 1293 & 3506 & & & \\
\hline BITPLA & 1318 & 429 & & & \\
\hline BIT9L5 & 1343 & 89.99 & & & \\
\hline B1T781: & 143 & 5168 & & & \\
\hline В11790 & 1655 & 044 & & & \\
\hline
\end{tabular}

(a) $<$ values $=$ below level of quantitation

(b) Red type = values above natural background and bold red are peak values in various lobes of vertical distribution. 


\subsection{ROM Schedule and Cost for Recommended Path Forward}

The schedule and rough order of magnitude (ROM) cost of the recommended path forward (Sections 5.1 through 5.5 ) is displayed in Table ?. It should be noted that the recommended path forward has been designed to provide a progessive and systematic approach to completing development of the vadose zone ${ }^{99} \mathrm{Tc}$ detector system and ultimately a full scale demonstration of a field ready system at Hanford. Al each step of the development process (sections 5.1 and 5.35.5 t the Detector Contractor is required to present results and demonstrate successful achievenent of objectives. At each of these gates WRPS will evaluate the results, provide comment as to reconmended path forward, and authorize progression to the next step. Note that the schedule shown indicates duration and sequence, if this project were to start October $1,2009$. If this work is authorized through DOE approval of a baseline change request, the actual schedule will be finalized to reflect the work authorization date.

Table 7. ROM Schednle and Cost for Proposed Path Forward

\begin{tabular}{|c|c|c|c|c|}
\hline \multirow[t]{2}{*}{ Activity } & \multicolumn{2}{|c|}{ Schedule } & \multicolumn{2}{|c|}{ ROM Cost } \\
\hline & Start & End & Organization & Cost $(\mathbf{K} \$)$ \\
\hline \multirow{2}{*}{$\begin{array}{l}\text { 5.1 Further testing at INL using the curent } \\
\text { detector system }\end{array}$} & Oet & Des & Detector Conlractor & 110 \\
\hline & 09 & 09 & WRPS $^{2}$ & 10 \\
\hline \multirow{3}{*}{$\begin{array}{l}\text { 5.2 Discussions with Hanford Site staff ion } \\
\text { needed requirements for field testing } \\
\text { and deployment }\end{array}$} & \multirow{3}{*}{$\begin{array}{r}\text { Dec } \\
09\end{array}$} & \multirow{3}{*}{$\begin{array}{r}\text { Jan } \\
10\end{array}$} & WRPS" & 30 \\
\hline & & & Other Hanford ${ }^{a}$ & 0 \\
\hline & & & Detector Coniraclor & 5 \\
\hline \multirow{2}{*}{$\begin{array}{l}5.3 \text { Development and testing of a new } \\
\text { prototype detector system(s) }\end{array}$} & \multirow{2}{*}{$\begin{array}{r}\text { Dec } \\
09\end{array}$} & \multirow{2}{*}{$\begin{array}{r}\text { Apr } \\
09\end{array}$} & Detector Contractor & 350 \\
\hline & & & WRPS $^{2}$ & 10 \\
\hline \multirow{2}{*}{$\begin{array}{l}5.4 \begin{array}{l}\text { Development of a vadose zone } \\
\text { deployable }\end{array} \\
\text { "Y Tc detector system }\end{array}$} & $\mathrm{Mar}$ & \multirow{2}{*}{$\begin{array}{r}\text { Aug } \\
10\end{array}$} & Detector Contractor $^{1}$ & 460 \\
\hline & 10 & & WRPS ${ }^{2}$ & 25 \\
\hline \multirow{6}{*}{$\begin{array}{l}\text { 5.5a Laboratory and field testing of a new } \\
\text { detector systen, ready for Hanford } \\
\text { Site deployment }\end{array}$} & \multirow{6}{*}{$\begin{array}{r}\text { Sep } \\
10\end{array}$} & \multirow{6}{*}{$\begin{array}{r}\text { Nov } \\
10\end{array}$} & Detector Conlractor & 24 \\
\hline & & & Laboratory Test ${ }^{e}$ & 20 \\
\hline & & & Other Hanford " & 0 \\
\hline & & & Direct Push Support ${ }^{\top}$ & 80 \\
\hline & & & $\mathrm{CHPRC}^{\mathrm{g}}$ & 50 \\
\hline & & & WRPS $^{a}$ & 30 \\
\hline \multirow{2}{*}{$\begin{array}{l}5.5 b \text { Analytic analysis of soil samples to } \\
\text { verify field measurements }\end{array}$} & Nov & \multirow{2}{*}{$\begin{aligned} \text { Feb } \\
11\end{aligned}$} & Analytic Analysis ${ }^{n}$ & 30 \\
\hline & 10 & & WRPS $^{a}$ & 20 \\
\hline
\end{tabular}

ROM = rough order of magnitude

Assumptions:

a) Mainly project management costs

b) The requirements meeting will be 2 days in duration 
c) WRPS costs includes salaries for all WRPS staff at the requirements meeting plus preparation and document costs.

d) Other Hanford (including contractors, DOE, and regulators) will participate at their expense as part of integration.

e) Costs for the laboratory test assume the use of a laboratory for 1 week ( 2 day preparation, 2 day demonstration. and 1 day further test and take down).

f) Includes all usual WRPS costs associated with a 4 week direct push campaign (1 day mobilization, 1 week for the initial push as well as gamma and moisture logging, 1 weeks for decommissioning including 1 foot technetium probe logging. 1 week for obtaining samples, and 2 days demobilization).

g) CHPRC costs as field work will be on Hanford land manased by them.

h) Costs for analysis of 3 samples taken from field test.

i) Final cost and schedule for laboratcy testing and field demonstration may be impacted based on functions and requirements established in $b$. 


\section{RPP-ENV-42667, Rev. 0}

6 References.

RPP-ENV-42008, F.M. Mann, K.J. Dunbar, C.F. Brown, Dennis Crass, and Douglas Akers, Evallation Plan for an In-Sin Vadose Zone Technetium-99 Detector. RPP-ENV-42008, Washinglon River Protection Solutions, LLC, Richland. Washington.

Serne et al.. 2009. R.J. Serne, D.F. Rucker. A.L. Ward. D.C. Lanigan. W. Um, M.W. Benecke, B.N. Bjonstad, Electrical Resistiviry Correlation to Vadose Zonte Sedinent and PoteWater Composition for the BC Cribs and Trenches Area. PNNL-17821. Pacific Northwest National Laboratory, Richland, Washington. 